\title{
Polymorphous Low-Grade Adenocarcinoma Located in the Maxillary Sinus
}

\author{
Maksiller Sinüs Yerleşimli Düşük Dereceli Polimorföz Adenokarsinom
}

\author{
Demet ETiT'1', Deniz ALTINEL' ', Ümit BAYOL' ', Ayça TAN' ', Özlem TÜRELiK'1, İbrahim ÇUKUROVA² \\ Departments of ${ }^{1}$ Pathology and ${ }^{2}$ Otorhinolaryngology, İmir Tepecik Education and Research Hospital, IZMIR, TURKEY
}

\begin{abstract}
Polymorphous low-grade adenocarcinoma is a malignant epithelial tumour with low metastatic rate and infiltrative growth pattern. The palate is the most common site. Paranasal sinuses are uncommon venues for polymorphous low-grade adenocarcinoma. Here, we report a polymorphous low-grade adenocarcinoma case of the maxillary sinus, a very rare location. Although it is a low grade malignancy, progression may develop after a long time. Therefore, polymorphous low-grade adenocarcinoma should be kept in mind in the differential diagnosis even in rare sites in the head and neck.
\end{abstract}

Key Words: Adenocarcinoma, Maxillary sinus, Paranasal sinuses

\begin{abstract}
ÖZ
Düşük dereceli polimorföz adenokarsinom, düşük metastaz oranı ve infiltratif büyüme paterni olan malign epitelyal bir tümördür. En sık damakta görülür. Paranazal sinüslerde çok nadirdir. Bu yazıda yerel yinelemeler gösteren nadir bir lokalizasyon olan maksiller sinüs yerleşimli bir düşük dereceli polimorföz adenokarsinom olgusu sunulmuştur. Düşük dereceli olmasına karşın, progresyon uzun zaman sonra olabilir. Bu nedenle baş boyun yerleşimli tümörlerde düşük dereceli polimorföz adenokarsinomlar ayırıcı tanıda düşünülmelidir.
\end{abstract}

Anahtar Sözcükler: Adenokarsinom, Maksiller sinüs, Paranazal sinüs

\section{INTRODUCTION}

Polymorphous low-grade adenocarcinoma (PLGA) is a malignant neoplasm characterized by cytologic uniformity, low aggressive rate and infiltrative growth pattern (1). PLGA is the second most common intraoral malignant salivary gland tumor accounting for $26 \%$ of all carcinomas in this location (2). The palate is the most common site, while the buccal mucosa, retromolar region, upper lip and the base of the tongue are frequent locations $(3,4)$. Major salivary and lacrimal glands, nasopharynx, nasal cavity and paranasal sinuses are uncommon sites for PLGA (5-17). We report a case of a recurrent PLGA located in the maxillary sinus.

\section{CASE REPORT}

A 35-year-old male presented first with a painless mass in the right maxillary sinus in 1988 which had destructed the bone of the nasal septum, and was diagnosed as a mixed tumor with local invasion. Following two recurrences in 2006 and 2008, the mass re-appeared in July 2009. Computerized tomography showed that a soft tissue mass completely filled the right maxillary sinus. Because of the significant destruction at the lateral orbital wall,

(Turk Patoloji Derg 2012, 28:274-277)

Received : 18.08.2010 Accepted : 01.02.2011 orbital floor and bony structures, the unilateral eye was proptotic in appearance (Figure 1). A hemimaxillectomy and right orbital exenteration was performed in the Otorhinolaryngology Clinic of our hospital, because of the widely invasive surrounding tissue mass.

On gross examination, the lesion was $6,5 \times 5 \times 4 \mathrm{~cm}$ in size, appearing as a white, solid mass with a whirling pattern on the cut surface, filling the right maxillary sinus completely, infiltrating into the orbital muscles and adipose tissue as well as orbital bone and soft tissue. No definitive capsule was identified. Histological examination showed tumor cells arranged in various amounts of solid, ductal, tubular and trabecular patterns. The tumor cells were mostly isomorphic in appearance, with round to oval or fusiform nuclei and bland nuclear chromatin and had a moderate amount of eosinophilic to clear cytoplasm. The cells were small and lacking nuclear atypia. Mitotic figures were rare and necrosis absent. Crystalloids resembling the tyrosinerich crystals were noted in focal areas. The surrounding muscle, fat and bone tissues were infiltrated by tumor cells. Perineural invasion was also noted. Immunohistochemical studies showed Cytokeratin 7 (CK), S100, SMA, p63, EMA positivity. CK20, GFAP, CK5/6, vimentin, CEA, CD10

Correspondence: Demet ETİT

Department of Pathology, İzmir Tepecik Education and Research Hospital,

IZMIR, TURKEY

E-mail: demetetit@yahoo.com Phone: +90 2322444444 
were negative. The diagnosis was PLGA with detailed morphological and immunohistochemical evaluation (Figures 2-6). Reconstructive surgery was also performed. The patient did well and was free of disease at the last followup, twenty months after the last surgical intervention.

\section{DISCUSSION}

PLGAs are malignant epithelial tumors with a low aggressive rate and infiltrative growth pattern (1). It is one of the commonest intraoral malignant salivary gland tumor (2).

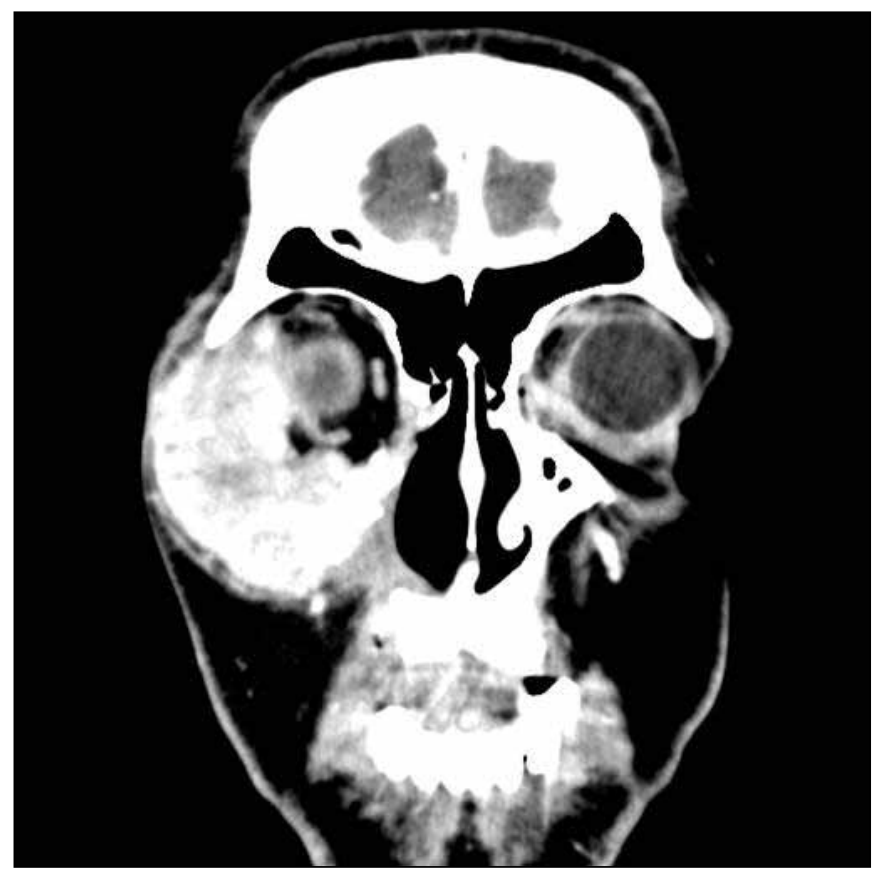

Figure 1: The maxillofacial computerized tomography (axial plan) shows a $7 \mathrm{~cm}$ mass arising in the right maxillary sinus eroding surrounding soft tissue and bones as as well as the orbital structures.

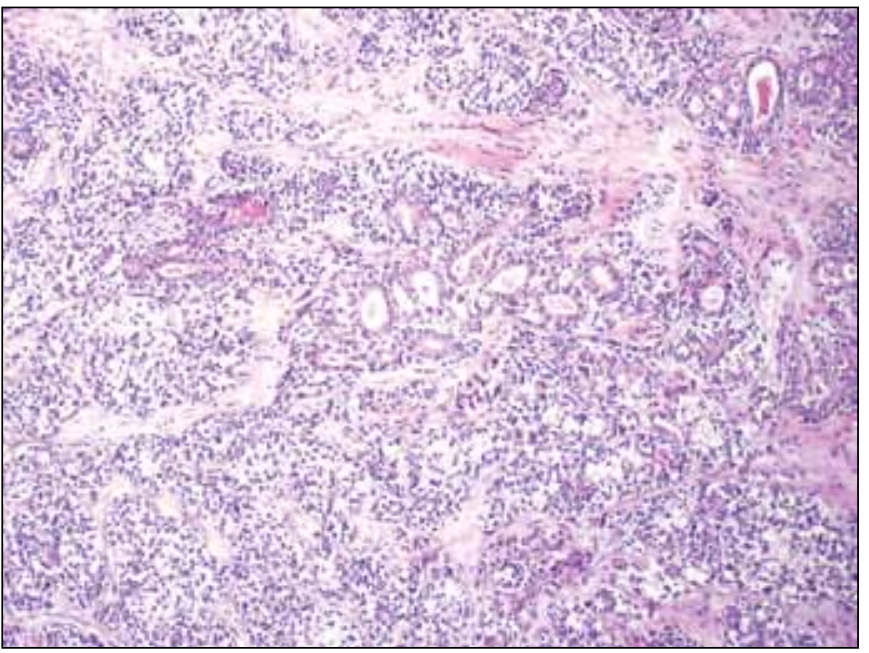

Figure 2: Various combinations of solid, tubular and trabecular patterns of the tumor (H\&E, x10).

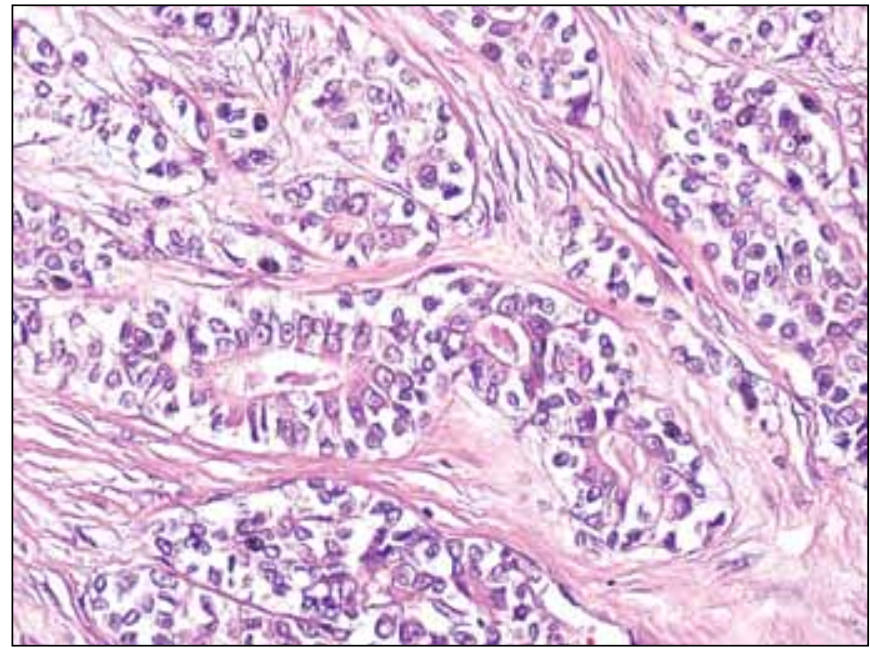

Figure 3: Small tubular structures showing central lumens (H\&E, $\mathrm{x} 20$ ).

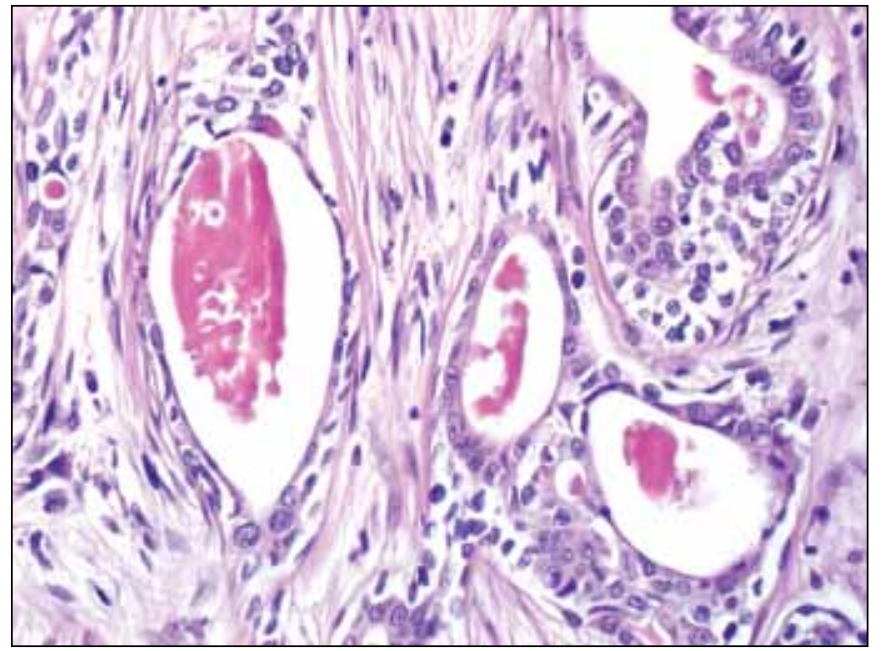

Figure 4: Ductal structures demonstrating central eosinophilic material (H\&E, x20).

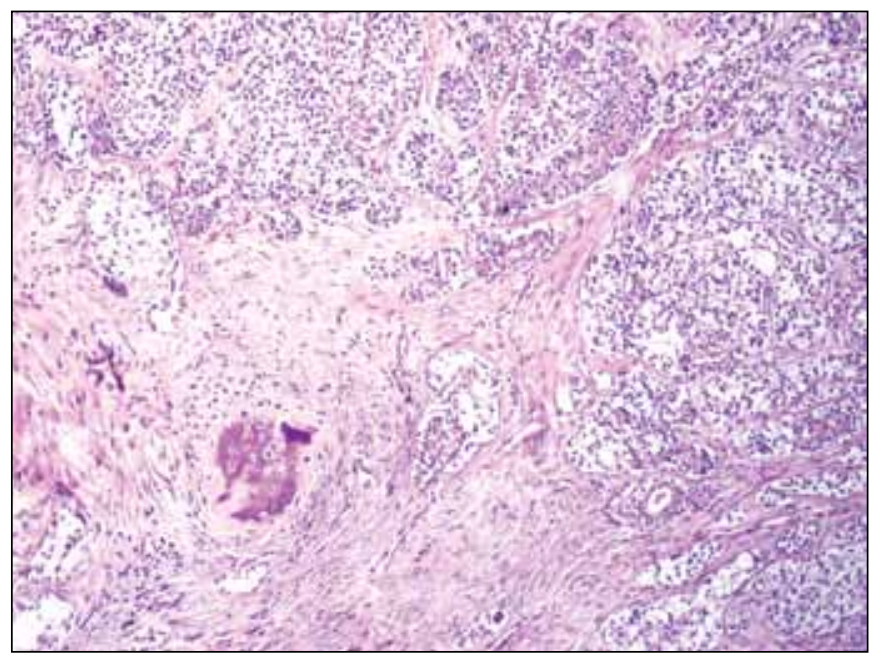

Figure 5: Bone invasion by the tumor (H\&E, x10). 


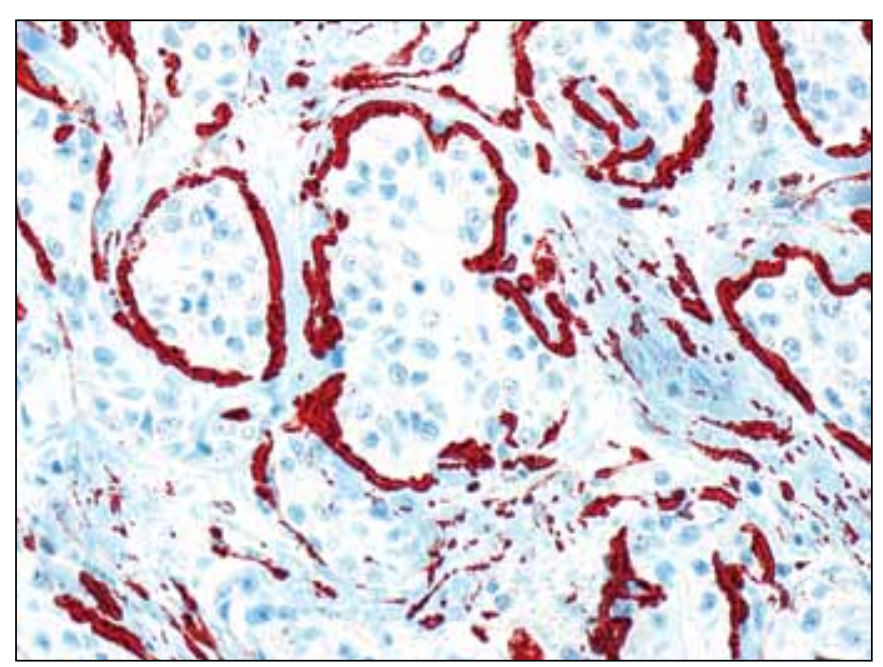

Figure 6: Smooth muscle actin positivity in the myoepithelial layer of the tumor nests (x20).

Typically, the palate is most commonly involved by PLGA. The buccal mucosa, retromolar region, upper lip and the base of the tongue are frequent locations $(3,4,18)$. Major salivary and lacrimal glands, nasopharynx, nasal cavity and paranasal sinuses are unexpected venues for PLGA (5-17).

There are only three reports mentioning a maxillary location of PLGA in the literature. One of them was intraosseous (19), the other simulated a maxillary odontogenic cyst around an impacted tooth (20). The case from Charous et al. is the single report to our knowledge that resembles the current case arising from the maxillary sinus (6).

PLGAs are dominantly seen in females. The age varies between 16-94 years with a mean of 59 years $(3,4)$. Although the present case was a 35 -year-old male when the specimen was sent to our pathology laboratory, the first mass appeared in his maxillary sinus when he was fourteen, meaning he is the youngest PLGA case in the literature to our knowledge.

Painless swelling is the most common symptom. The existence of the lesion has been observed from weeks to 40 years (3). Our case came with a painless swelling on the right side of the face 21 years ago, then presented three more times in the last three years with local recurrences.

PLGA occasionally shows a firm, well-circumscribed, nonencapsulated mass with an average size of $2.2 \mathrm{~cm}$ (3) while the current case was $6.5 \mathrm{~cm}$ in greatest dimension as a recurrent lesion.

PLGA cases appear in a variety of configurations in trabecular, tubular, solid, papillary and cribriform patterns, which is a significant feature for these carcinomas (1). The current case also showed a tubular appearance.

The neoplastic cells of the PLGAs show immunoreactivity with antibodies to cytokeratin, vimentin, S-100 protein, CEA, GFAP, EMA $(3,21,22)$. In our case, CK7, S100, SMA, p63, EMA positivity and CK20, GFAP, CK5/6, vimentin, CEA, CD10 negativity were observed.

Pleomorphic adenoma (PA) and adenoid cystic carcinoma (AdCC) are included in the differential diagnosis. Distinguishing PLGA from PA is often not possible on a cytomorphologic basis. PA is composed of proliferating epithelial, stromal and myoepithelial cells which lack an infiltrative pattern that is characteristic for PLGA (1). Although PA of the minor glands are often unencapsulated, they do not infiltrate the adjacent tissues such as fat, muscle or bone. Myxochondroid and chondroid areas are present more commonly in PA than PLGA (1).

Distinguishing PLGA from AdCC is mostly based on cytologic properties. Cells in PLGA are more round to oval with bland nuclear chromatin and a moderate amount of eosinophilic to clear cytoplasm, in contrast to AdCC that has more basaloid features. Furthermore, large pseudocystic spaces are more characteristic for AdCC than PLGA. The solid areas of PLGA also lack the nuclear pleomorphism, small and angular nuclei, necrosis and mitotic activity that are often seen in the solid variant of $\operatorname{AdCC}(3,22,23)$. The current case was an infiltrative lesion with no significant or atypical mitosis and necrosis.

Treatment includes complete surgical excision. Maxillectomy and right orbital exenteration were performed in our case. Radiotherapy (RT) was performed after both the first and the second operations and chemotherapy was carried out after the last operation together with RT.

PLGA has a relatively good prognosis $(3,4,24)$. Our patient did well postoperatively and he was free of disease at the last follow-up despite the three recurrences in a 21-year period.

In conclusion, the maxillary sinus is a very rare location for PLGA. As its name implies, this is a low-grade malignancy and the progression and the treatment can take a long time, sometimes causing vital tissue loss as in the current case. PLGA should be kept in mind in the differential diagnosis, even in rare sites in the head and neck.

\section{ACKNOWLEDGEMENT}

We would like to respectfully offer our regards to Prof. Dr. Feriha Öz for her experience and knowledge on the basis of the initial pathology report in 1988. 


\section{REFERENCES}

1. Luna MA, Wenig BM: Polymorphous low-grade adenocarcinoma. In Barnes L, Eveson JV, Reichart P, Sidransky D (Eds): Pathology and Genetics of Head and Neck Tumours, Lyon, IARC Press, 2005, 225-226

2. Waldron CA, el-Mofty SK, Gnepp DR: Tumors of the intraoral minor salivary glands: a demographic and histologic study of 426 cases. Oral Surg Oral Med Oral Pathol 1988, 66: 323-333

3. Castle JT, Thompson LD, Frommelt RA, Wenig BM, Kessler HP: Polymorphous low grade adenocarcinoma: a clinicopathologic study of 164 cases. Cancer 1999, 86: 207-219

4. Evans HL, Luna MA: Polymorphous low-grade adenocarcinoma: a study of 40 cases with long-term follow up and an evaluation of the importance of papillary areas. Am J Surg Pathol 2000, 24 $1319-1328$

5. Arathi N, Bage AM: Polymorphous low-grade adenocarcinoma of parotid gland: a rare occurrence. Indian J Pathol Microbiol 2009, 52: 103-105

6. Charous DD, Cunnane MF, Rosen MR, Keane WM: Recurrent polymorphous low-grade adenocarcinoma manifesting as a sinonasal mass: a case report. Ear Nose Throat J 2005, 84:356-357

7. Garzaro M, Pecorari G, Landolfo V, Campisi P, Reali A, Giordano $C$ : Nasopharyngeal polymorphous low-grade adenocarcinoma in a patient with nonfunctioning pituitary macroadenoma. B-ENT 2010, 6: 59-62

8. Gonzalez-Lagunas J, Alasa-Caparros C, Vendrell-Escofet G, Huguet-Redecilla P, Raspall-Martin G: Polymorphous lowgrade adenocarcinoma of the nasal fossa. Med Oral Patol Oral Cir Bucal 2005, 10: 367-370

9. Lengyel E, Somogyi A, Godeny M, Szerdahelyi A, Nemeth G: Polymorphous low-grade adenocarcinoma of the nasopharynx. Case report and review of the literature. Strahlenther Onkol 2000 , 176: $40-42$

10. Lloreta J, Serrano S, Corominas JM, Ferres-Padro E: Polymorphous low-grade adenocarcinoma arising in the nasal cavities with an associated undifferentiated carcinoma. Ultrastruct Pathol 1995, 19: 365-370

11. Merchant WJ, Cook MG, Eveson JW: Polymorphous low-grade adenocarcinoma of parotid gland. Br J Oral Maxillofac Surg 1996, 34: $328-330$

12. Nagao T, Gaffey TA, Kay PA, Minato H, Serizawa H, Lewis JE: Polymorphous low-grade adenocarcinoma of the major salivary glands: report of three cases in an unusual location. Histopathology 2004, 44: 164-171
13. Pintor MF, Figueroa L, Martinez B: Polymorphous low grade adenocarcinoma: review and case report. Med Oral Patol Oral Cir Bucal 2007, 12: E549-551

14. Ritland F, Lubensky I, LiVolsi VA: Polymorphous low-grade adenocarcinoma of the parotid salivary gland. Arch Pathol Lab Med 1993, 117: 1261-1263

15. Ruiz-GodoyL, SuarezL, Mosqueda A, Meneses A: Polymorphous low-grade adenocarcinoma of the parotid gland. Case report and review of the literature. Med Oral Patol Oral Cir Bucal 2007, 12: E30-33

16. Tamiolakis D, Thomaidis V, Tsamis I, Kariki E, Kotini A, Lambropoulou M, Boglou P, Papadopoulos N: Polymorphous low grade adenocarcinoma of the parotid gland. Cytological, histological and immunohistochemical features and review of the literature. Acta Medica (Hradec Kralove) 2004, 47: 3-6

17. Wei YC, Huang CC, Chien CY, Hwang JC, Chen WJ: Polymorphous low-grade adenocarcinoma of the nasopharynx: a case report and brief review. J Clin Pathol 2008, 61: 1124-1126

18. Scally CM, Irwin ST, Nirodi N: Low grade polymorphous adenocarcinoma of a minor salivary gland. J Laryngol Otol 1988, 102: $284-287$

19. Sato T, Indo H, Takasaki T, Kawabata Y, Morita Y, Noikura T: A rare case of intraosseous polymorphous low-grade adenocarcinoma (PLGA) of the maxilla. Dentomaxillofac Radiol 2001, 30: 184-187

20. Geha H, Boland FX, Francois A, Tardif A, Peron JM: Polymorphous low-grade adenocarcinoma of the maxilla simulating an odontogenic cyst. Rev Stomatol Chir Maxillofac 2010, 111: 105-107

21. Wenig BM, Harpaz N, DelBridge C: Polymorphous low-grade adenocarcinoma of seromucous glands of the nasopharynx. A report of a case and a discussion of the morphologic and immunohistochemical features. Am J Clin Pathol 1989, 92: 104-109

22. Perez-Ordonez B, Linkov I, Huvos AG: Polymorphous low-grade adenocarcinoma of minor salivary glands: a study of 17 cases with emphasis on cell differentiation. Histopathology 1998, 32: 521-529

23. Brown AM, Castle J, Hebbachi AM, Gibbons GF: Administration of n-3 fatty acids in the diets of rats or directly to hepatocyte cultures results in different effects on hepatocellular ApoB metabolism and secretion. Arterioscler Thromb Vasc Biol 1999, 19: $106-114$

24. Evans HL, Batsakis JG: Polymorphous low-grade adenocarcinoma of minor salivary glands. A study of 14 cases of a distinctive neoplasm. Cancer 1984, 53: 935-942 